CURRENT ISSUES IN INTERNATIONAL TRADE 


\section{CURRENT ISSUES IN ECONOMICS}

General Editor: David Greenaway, University of Nottingham

Current Issues in Development Economics

Edited by V. N. Balasubramanyam and Sanjaya Lall

Current Issues in the Economics of Welfare

Edited by Nicholas Barr and David Whynes

Current Issues in Industrial Economics

Edited by John Cable

Current Issues in Financial and Monetary Economics

Edited by Kevin Dowd and Mervyn K. Lewis

Current Issues in International Trade (Second Edition)

Edited by David Greenaway

Current Issues in Macroeconomics

Edited by David Greenaway

Current Issues in Microeconomics

Edited by John D. Hey

Current Issues in Public Sector Economics

Edited by Peter M. Jackson

Current Issues in International Monetary Economics

Edited by David T. Llewellyn and Chris Milner

Current Issues in Agricultural Economics

Edited by A. J. Rayner and David Colman

Current Issues in Labour Economics

Edited by David Sapsford and Zafiris Tzannatos 


\section{Current Issues in International Trade}

Second Edition

Edited by

David Greenaway

Professor of Economics

University of Nottingham

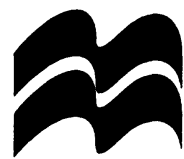


Published by

MACMILLAN PRESS LTD

Houndmills, Basingstoke, Hampshire RG21 6XS

and London

Companies and representatives

throughout the world

A catalogue record for this book is available

from the British Library.

ISBN 978-0-333-57749-3 ISBN 978-1-349-24563-5 (eBook)

DOI 10.1007/978-1-349-24563-5

First published in the United States of America 1996 by

ST. MARTIN'S PRESS, INC.,

Scholarly and Reference Division,

175 Fifth Avenue,

New York, N.Y. 10010

ISBN 978-0-312-12594-3

Library of Congress Cataloging-in-Publication Data

Current issues in international trade / edited by David Greenaway. -

2nd ed.

p. $\mathrm{cm}$.

Includes bibliographical references and indexes.

ISBN 978-0-312-12594-3

1. Commercial policy. 2. International economic relations.

I. Greenaway, David.

HF1411.C83 1996

$382^{\prime} .3-\mathrm{dc} 20 \quad 95-5638$

CIP

Selection and editorial matter (c) David Greenaway 1985, 1996

Individual chapters $\odot$ Ali M. El-Agraa, Bruno S. Frey and Hannelore Weck-Hannemann,

Carl Hamilton and G. V. Reed, Henryk Kierzkowski, Chris Milner, J. Peter Neary, Ian

Steedman and J. S. Metcalfe, Klaus Stegemann, P. K. M. Tharakan and G. Calfat 1996

All rights reserved. No reproduction, copy or transmission of this publication may be made without written permission.

No paragraph of this publication may be reproduced, copied or transmitted save with written permission or in accordance with the provisions of the Copyright, Designs and Patents Act 1988, or under the terms of any licence permitting limited copying issued by the Copyright Licensing Agency, 90 Tottenham Court Road, London W1P 9HE.

Any person who does any unauthorised act in relation to this publication may be liable to criminal prosecution and civil claims for damages.

First edition 1985

Second edition 1996

$\begin{array}{llllllllll}10 & 9 & 8 & 7 & 6 & 5 & 4 & 3 & 2 & 1\end{array}$

$\begin{array}{llllllllll}05 & 04 & 03 & 02 & 01 & 00 & 99 & 98 & 97 & 96\end{array}$ 


\section{Contents}

LIST OF TABLES $\quad$ iX

LIST OF FIGURES vii

PREFACE $\quad \mathrm{X}$

NOTES ON THE CONTRIBUTORS $\quad \mathrm{xi}$

1 Models of International Trade in Differentiated Goods

Henryk Kierzkowski 1

2 Capital Goods and the Pure Theory of Trade

Ian Steedman and J. S. Metcalfe 20

3 Theory and Policy of Adjustment in an Open Economy

J. Peter Neary

4 Empirical Analyses of International Trade Flows

P. K. M. Tharakan and G. Calfat

5 Strategic Trade Policy

Klaus Stegemann

6 Economic Aspects of Voluntary Export Restraints

Carl Hamilton and G. V. Reed 
7 Empirical Analysis of the Welfare Effects of Commercial Policy

Chris Milner

8 The Political Economy of Protection

Bruno S. Frey and Hannelore Weck-Hannemann

9 International Economic Integration

Ali M. El-Agraa

END-NOTES

REFERENCES

AUTHOR INDEX

SUBJECT INDEX 


\section{List of Figures}

1.1 Cournot reaction functions 5

1.2 Equilibrium in the Krugman model 10

1.3 A consumer's compensating function 13

1.4 Alternative specifications of a horizontally differentiated $\begin{array}{ll}\text { commodity } & 14\end{array}$

1.5 A model of vertical product differentiation 17

2.1 Relative commodity prices and the wage rental frontier 22

2.2 The division of the net product between wages and interest 23

2.3 Choice of technique and the interest rate 24

2.4 Choice of technique, consumption and growth 26

2.5 Consumption possibility frontiers 29

2.6 Multiple equilibria $\quad 32$

2.7 Multiple equilibria and the $\mathrm{H}-\mathrm{O}-\mathrm{S}$ price theorem 32

2.8 Alternative interest rates, capital intensity and the product price ratio $\quad 35$

3.1 Adjustment to a deterioration in the terms of trade 41

3.2 Short-run labour market disequilibrium 42

3.3 Short-run labour market disequilibrium in wage-price space

3.4 Simultaneous adjustment of wages and prices 46

3.5 Real exchange rate overshooting as a result of
computerisation in the traded goods sector

3.6 Intersectoral capital reallocation 49

3.7 Equilibrium production patterns for a small country in a
three-commodity world

3.8 Determination of steady-state capital:labour ratio 53 
3.9 Effect on industrial structure of a fall in population growth rate from $n$ to $n^{\prime}$

5.1 Brander-Spencer profit shifting

6.1 The effects of a VER on the importing country

6.2 The effects of a VER on the exporting country

6.3 The effects of a VER when only one exporter is restricted

6.4 The imposition of a VER by one of two importing countries

7.1 The effects of trade liberalisation

7.2 The process of applied general equilibrium analysis

7.3 Welfare cost of rationing and rent seeking

8.1 The optimal amount of lobbying for tariff protection

9.1 Trade creation and trade diversion

9.2 Preference for industrial production

9.3 Scale economies and customs union formation

9.4 A customs union with economies of scale and domestic distortions

9.5 Customs unions and the terms of trade

9.6 UTR versus customs unions

9.7 Factor mobility in a common market

9.8 The traditional analysis of economic and monetary union 


\section{List of Tables}

6.1 Incidence of US, EC and Japanese quantitative restrictions on imports in 1986

6.2 Korea: restrictive trade measures affecting exports in selected sectors (as of November 1980)

6.3 Trade barriers against clothing imports from Hong Kong, average 1981-83

6.4 Rent income from VERs to Hong Kong from exports of clothing

7.1 Partial equilibrium estimates of multilateral tariff reductions

7.2 Maximum estimated deadweight gains and employment losses if VER imports increased by $50 \%$ in the case of Swedish textiles and clothing imports (1977)

7.3 A comparison of costs of alternative trade restrictions

7.4 Pattern of DRC ratios by industry in Madagascar, 1983

7.5 General equilibrium welfare effects of Swiss tariffcutting proposal in Tokyo Round by trading bloc

7.6 Welfare gains from trade liberalisation in Turkey

7.7 Simulations results of Baldwin and Krugman model

7.8 Summary of changes in a US-Canadian free trade area

8.1 Tariff revenue as a proportion of central government revenue, 1980-85 selected developing countries

9.1 Integration effects in an AIDS model of trade 


\section{Preface}

The Current Issues series now extends to 11 volumes, more or less covering the entire undergraduate syllabus. The pilot for the series was Current Issues in International Trade, published in 1985. The success of this book as a supplement to a core text on International Trade courses encouraged Macmillan to press on to a full series and encouraged me to take on the job of editing it. The series has now come full circle and we have decided to integrate Current Issues in International Trade into it: hence this second edition.

This edition preserves the essential objective of the first edition, namely a set of essays which are accessible to final-year students and which provide some insight to 'current issues'. The coverage in terms of topics is much the same as the first edition. Some chapters are almost identical, since the literature has not moved on significantly. This is true, for instance, of those dealing with adjustment in the open economy and capital goods and trade. In other cases, however, substantial revision was required to take account of recent developments. This is especially true of those chapters with a significant empirical content: for example, the chapters dealing with empirical analyses of trade flows and the political economy of protection.

I hope very much that instructors and students find this a useful collection of essays. I am grateful to the contributors for their cooperation in putting the volume together and hope that they too are happy with the final product. 


\section{Notes on the Contributors}

G. Calfat is Research Officer at the University of Antwerp.

Ali M. El-Agraa is Professor of Economics at Fukuoka University, Japan.

Bruno S. Frey is Professor of Economics at the University of Zurich.

David Greenaway is Professor of Economics at the University of Nottingham.

Carl Hamilton is Deputy Director at the Institute for International Economic Studies, Stockholm.

Henryk Kierzkowski is Professor of Economics at the Graduate Institute of International Studies, Geneva.

J. S. Metcalfe is Professor of Economics at the University of Manchester.

Chris Milner is Professor of International Economics at the University of Nottingham.

J. Peter Neary is Professor of Economics at University College, Dublin.

G. V. Reed is Senior Lecturer in Economics at the University of Nottingham.

Ian Steedman is Professor of Economics at Manchester Metropolitan University.

Klaus Stegemann is Professor of Economics at Queens University, Ontario. 
xii Notes on the Contributors

P. K. M. Tharakan is Professor of Economics at the University of Antwerp.

Hannelore Weck-Hannemann is Research Officer at the University of Zurich. 